\title{
Features of physiological and biochemical processes of Prunus armeniaca and Ficus carica in water stress conditions
}

\author{
Tatiyana Gubanova*, Ruslana Pilkevich, Ivan Paliy, Oksana Grebennikova, and Ekaterina \\ Melkozeorova \\ The Nikitsky Botanical Gardens - National Scientific Center of the RAS, Laboratory of biochemistry, \\ physiology and reproductive biology of plants, Nikita, Yalta, 298648 Russian Federation
}

\begin{abstract}
Studies results of drought resistance degree of 4 Ficus carica varieties and 4 Prunus armeniaca varieties are presented. It was established that genotypes of 'Sary Stambulskiy' and 'Sabrucia Rozovaya' (F. carica), 'Kazachok' and 'Professor Smykov' (P. armeniaca) are characterized by a high level of adaptation to inadequate water supply. Their leaves show an increased ability to retain moisture in the wilting process and the ability to carry out the fullest possible tissue reparation after critical water loss. The relationship between peroxidase and polyphenol oxidase activity, as well as the concentration of proline with the implementation of protective mechanisms against the negative influence of dehydration was revealed. Characteristics of primary photosynthesis processes in water stress conditions were given. It was found that in $F$. carica varieties, the rapid fluorescence phase parameters are the most sensitive to dehydration. In P. armeniaca varieties, water stress causes an increase in basic fluorescence and decrease in variable.
\end{abstract}

\section{Introduction}

Studies of physiological and biochemical stability mechanisms and features of their implementation at different plant organism's integration levels serve as a basis for both further development of the adaptation and introduction theory and for solving problems of practical crop production.

The climate of the Southern coast of Crimea allows to grow a fairly wide range of southern fruit crops, including Ficus carica and Prunus armeniaca varieties. However, often repeated droughts in the spring/summer period have a negative impact on their condition. It is known that the action of stressors is accompanied by the intensification of non-enzymatic oxidation processes and the formation of active oxygen forms $[1,2]$. Mechanisms for removing AOF using enzymatic and non-enzymatic antioxidant systems are developed to mitigate or protect against stressful induced oxidative damage in plants, which include oxidation-reduction enzymes (superoxide dismutase, catalase, peroxidase, etc.) and protective compounds (phenolic substances, ascorbic acid, proline, etc.) [3].

\footnotetext{
*Corresponding author: gubanova-65@list.ru
} 
Several authors note the high sensitivity of chlorophyll fluorescence processes to external influences of different nature. In particular, it is known that the nature of the CFI curve allows to obtain objective information about changes in photosynthetic processes associated with both the development of adaptive syndrome and with irreversible violations in the photosynthetic apparatus operation, which in turn allows to obtain an objective characteristic of the studied plant species stability [5-10]. In this regard, the aim of our research was to identify the functional relationship of peroxidase, polyphenyloxidase activity and proline content with the degree of drought resistance of certain F. carica and $P$. armeniaca varieties, as well as the peculiarities of photosynthetic processes course in water stress conditions.

\section{Objects and methods of research}

The following P. armeniaca varieties were chosen as research objects: 'Alupkinsky', 'Krymskiy Amur', 'Kazachok' and 'Professor Smykov', and 4 F. carica varieties: 'Krymskiy Cherniy', 'Sary Stambulskiy', 'Sabrucia Rozovaya' and 'Opylitel Nikitsky'.

Physiological and biochemical parameters in the leaves of F. carica varieties were determined in full saturation (control) condition, after 4 hours of wilting (experiment, 20$25 \%$ water loss), as well as after leaf tissue water availability restoration; in the leaves of P. armeniaca varieties - after 15 hours (water loss 25-30\%). Determination of proline content was carried out according to modified Chinard method using ninhydrin reagent [11]. Peroxidase activity was determined spectrophotometrically by the oxidation reaction rate of benzidine, polyphenol oxidase - in the presence of pyrocatechin and $\mathrm{p}$ phenylenediamine [12].

The condition of the photosynthetic apparatus was evaluated by changing the parameters of chlorophyll fluorescence induction (CFI) using the portable chronofluorimeter "Floratest". Fluorescence variable (Fv), photosynthetic activity (Fm- Fst) /Fm, as well as fluorescence decline coefficient (viability index) - Fm/Fst were calculated. [13].

The study of the water regime parameters was carried out under the controlled leaves wilting conditions during the most arid periods, when extreme weather conditions were affecting the plants contributing to the development of hydrothermal stress. The waterholding capacity of leaf tissues was determined by the speed and amount of water loss over a certain period of time. The degree of reparation capabilities was assessed by the damaged areas of laminas (necrosis, infiltration spots) after restoration of leaves water status [14].

Experiments were carried out in threefold repetition. MS Excel 2007 programs were used for statistical processing. The reliability of differences between the options was calculated according to the Student's T-criterion at 5\% significance level. The tables represent the average values of the definitions and their standard errors.

\section{Results and Discussion}

In the period from 2017 to 2020 , the parameters of the water regime (real water deficit, water-retaining forces) were studied in $4 F$. carica and $4 P$. armeniaca varieties. Based on the results obtained, genotypes with a high degree of drought resistance were identified, which were characterized by the economical water consumption in the wilting process and good reparation abilities after turgidity recovery: F. carica varieties - 'Sabrucia Rozovaya' and 'Sary Stambulskiy', P. armeniaca varieties - 'Kazachok' and 'Professor Smykov'.

In the process of experimental wilting in May (6 hours), the loss of water by apricot leaf tissues varied between 14.5-20.5\%. Leaves of 'Kazachok' and 'Alupkinsky' varieties (having 
close field water-bearing nature) showed similar dynamics of moisture loss. After rehydration of the leaves, both genotypes had a high turgidity degree (96-98\%). Significant differences in their adaptive capabilities manifest after 12 hours of wilting. 'Kazachok' variety has twice as much leaf's tissues restoring normal turgor. In June, water output is much more intense. Having weak retaining forces, 'Alupkinsky' variety showed moisture loss amount in the first two hours 2-3 times higher than May values. After 8 hours of wilting, the reparation degree of leaf surface area amounted to $90-100 \%$ in the studied genotypes. Long lasting wilting (12 hours) causes serious damage to leaf tissue manifested in: more stable varieties 'Professor Smykov' and 'Kazachok' - inability to restore complete turgor; less resistant - in unsatisfactory reparation abilities (45-55\%). As a rule, JulyAugust weather conditions tend to often become critical for apricot. In these months, water deficiency in leaves reaches maximum values in tissues of 'Kazachok' (30.5\%) and 'Krymskiy Amur' (22.5\%) varieties.

Table 1. Water retention and reparation capacity of $P$. armeniaca varieties' leaves (July)

\begin{tabular}{|c|c|c|c|c|c|c|c|c|c|c|}
\hline \multirow[b]{2}{*}{ Variety } & \multirow{2}{*}{$\begin{array}{c}\text { Water } \\
\text { content in } \\
\text { leaves, \% } \\
\text { of raw } \\
\text { weight }\end{array}$} & \multirow{2}{*}{\begin{tabular}{|} 
Water \\
content in \\
leaves, full \\
water \\
supply, \% of \\
raw weight \\
\end{tabular}} & \multirow{2}{*}{$\begin{array}{c}\text { Water } \\
\text { deficiency } \\
\text { in leaves, \% }\end{array}$} & \multicolumn{4}{|c|}{$\begin{array}{l}\text { Water losses in the } \\
\text { wilting process, } \%\end{array}$} & \multirow{2}{*}{$\begin{array}{c}\text { Leaves } \\
\text { restoring } \\
\text { turgor, } \%\end{array}$} & \multirow{2}{*}{$\begin{array}{c}\text { Water } \\
\text { loss after } \\
12 \text { hours, } \\
\%\end{array}$} & \multirow{2}{*}{$\begin{array}{l}\text { Leaves } \\
\text { restoring } \\
\text { turgor, \% }\end{array}$} \\
\hline & & & & $\begin{array}{c}2 \\
\text { hours }\end{array}$ & $\begin{array}{c}4 \\
\text { hours }\end{array}$ & $\begin{array}{c}6 \\
\text { hours }\end{array}$ & $\begin{array}{c}8 \\
\text { hours }\end{array}$ & & & \\
\hline 'Alupkinsky' & $59.7 \pm 1.7$ & $67.9 \pm 2.4$ & 22.1 & 11.7 & 18.2 & 23.1 & 27.3 & 95 & 34.6 & 38 \\
\hline 'Kazachok' & $59.8 \pm 1.1$ & $69.7 \pm 1.3$ & 30.4 & 8.7 & 16.7 & 22.1 & 25.4 & 86 & 34.1 & 88 \\
\hline $\begin{array}{l}\text { 'Krymskiy } \\
\text { Amur' }\end{array}$ & $63.3 \pm 1.9$ & $70.3 \pm 2.6$ & 22.5 & 9.8 & 15.1 & 19.2 & 22.8 & 92 & 27.6 & 53 \\
\hline $\begin{array}{l}\text { 'Professor } \\
\text { Smykov' }\end{array}$ & $64.7 \pm 1.2$ & $69.3 \pm 1.5$ & 20.6 & 12.5 & 17.0 & 20.7 & 23.5 & 90 & 38.5 & 86 \\
\hline
\end{tabular}

After 12 hours of wilting, leaves of the studied varieties lost $30-40 \%$ moisture, after which the level of turgor recovery amounted to 35 to $55 \%$ of the leaf surface area in genotypes with low resistance, and $85-90 \%$ - in more resistant ones. Relatively stable varieties are characterized by less water loss, relatively stable dynamics of its return and a sufficient turgidity degree $(90-100 \%)$. The loss of $14-20 \%$ moisture by leaf tissues is sublethal for the studied apricot varieties. As a result, in the conditions of summer water stress, 'Kazachok' and 'Professor Smykov' varieties possessed increased water-retaining and reparation characteristics. The poor ability to retain moisture and restore the tissues turgor after withering was shown by 'Krymskiy Amur' and 'Alupkinskiy'.

In May, the leaves of the studied F. carica varieties after 3 hours of wilting lot from 14.5 to $19 \%$ of moisture, which did not exceed the sublethal water deficit in varieties 'Sary Stambulskiy' and 'Sabrucia Rozovaya'. Due to this, the amount of restored leaf surface area in them reached $96-100 \%$, whereas the remaining two genotypes had a reparation rate of $70-85 \%$. In June after wilting for a duration of 5 hours, no variety had a complete restoration of leaf turgor, satisfactory turgidity was noted only in 'Sary Stambulskiy' and 'Sabrucia Rozovaya' - 95 and 92\% respectively. The weakest ability to retain moisture and low level of turgor restoration were shown by leaves of 'Krymskiy Cherniy' variety. In JulyAugust for 4 hours of wilting, the leaves of this variety can lose up to $36 \%$ of water, after which reparation is no more than $55 \%$ of the leaf surface area. In these months during the same period the remaining genotypes give away half as much moisture (15-20\%); however, tissue recovery after water saturation is carried out by less than $90 \%$. 
Table 2. Water retention and reparation capacity of Ficus carica varieties' leaves (July)

\begin{tabular}{|c|c|c|c|c|c|c|c|c|}
\hline \multirow{2}{*}{ Genotype } & \multirow{2}{*}{$\begin{array}{c}\text { Water } \\
\text { content } \\
\text { in } \\
\text { leaves, } \\
\% \text { of raw } \\
\text { weight }\end{array}$} & \multirow{2}{*}{$\begin{array}{c}\text { Water } \\
\text { content in } \\
\text { leaves, full } \\
\text { water } \\
\text { supply, \% of } \\
\text { raw weight }\end{array}$} & \multirow{2}{*}{$\begin{array}{c}\text { Water } \\
\text { deficiency } \\
\text { in leaves, } \\
\%\end{array}$} & \multicolumn{4}{|c|}{ Water losses in the wilting process, $\%$} & \multirow[t]{2}{*}{$\begin{array}{l}\text { Leaves restoring } \\
\text { turgor, } \%\end{array}$} \\
\hline & & & & 1 hour & 2 hours & 3 hours & 4 hours & \\
\hline $\begin{array}{l}\text { 'Krymskiy } \\
\text { Chernyiy' }\end{array}$ & $67.5 \pm 2.1$ & $71.1 \pm 2.6$ & $12.4 \pm 1.7$ & $14.4 \pm 1.3$ & $21.2 \pm 1.9$ & $28.4 \pm 2.3$ & $35.6 \pm 3.1$ & 53 \\
\hline $\begin{array}{l}\text { 'Opylitel } \\
\text { Nikitsky' }\end{array}$ & $67.5 \pm 2.0$ & $70.1 \pm 2.4$ & $10.7 \pm 1.5$ & $9.7 \pm 1.1$ & $13.2 \pm 1.4$ & $16.5 \pm 1.8$ & $20.3 \pm 2.5$ & 76 \\
\hline $\begin{array}{l}\text { 'Sabrucia } \\
\text { Rozovaya' }\end{array}$ & $70.0 \pm 1.6$ & $71.8 \pm 1.8$ & $4.5 \pm 1.1$ & $7.8 \pm 0.9$ & $11.3 \pm 1.2$ & $14.2 \pm 1.4$ & $17.3 \pm 1.7$ & 88 \\
\hline $\begin{array}{l}\text { 'Sary } \\
\text { Stambulskiy' }\end{array}$ & $69.4 \pm 1.4$ & $70.6 \pm 1.5$ & $7.5 \pm 0.8$ & $7.0 \pm 0.7$ & $10.7 \pm 1.0$ & $14.0 \pm 1.2$ & $18.3 \pm 1.1$ & 90 \\
\hline
\end{tabular}

During the mass fruit ripening period, the loss of $10-15 \%$ of moisture by figs leaves is a sublethal water deficiency. In the absence of fruit load, the level of permissible sublethal moisture loss rises to $15-20 \%$ and can reach $30 \%$ in 'Sary Stambulskiy' variety. During periods of extreme exposure to arid factors, the leaves' water loss in 'Sary Stambulskiy' and 'Sabrucia Rozovaya' hydrothermal stress-resistant genotypes in the first three hours of wilting did not exceed $20 \%$. The minimum level of water retaining forces, as well as in most cases, unsatisfactory turgidity, was shown by 'Krymskiy Cherniy'. Leaves' tissue dehydration degree of this variety after 2 hours of wilting varies between $8-25 \%$ depending on weather conditions indicating low stability of the water regime. 'Opylitel Nikitsky' variety is characterized by an average level of drought resistance.

In the study framework of physiological and biochemical mechanisms of water stress resistance of $P$. armeniaca various genotypes, biochemical parameters in the conditions of controlled wilting were determined. It was revealed that changes in proline content concentration and enzyme activity in apricot leaves were due to varietal features. At the beginning of the summer season in the leaves of drought-resistant varieties, peroxidase activity was almost unchanged, and in sensitive to dehydration - increased. The activity of polyphenol oxidase increased with full leaves' water availability, with wilting-changed in a variety of directions. Turgor restoration led to an increase in polyphenol oxidase activity in the leaves of drought-resistant varieties.

In the period of maximum drought probability on the Southern Crimea shore, upon reaching the sublethal water deficit level $(35 \%)$ polyphenol oxidase activity in unstable 'Krymskiy Amur' variety increased by $81 \%$, and 'Alupkinsky' - decreased by $20 \%$. Activation of this enzyme in dehydration conditions has also been noted in droughtresistant varieties 'Kazachok' and 'Professor Smykov'. 


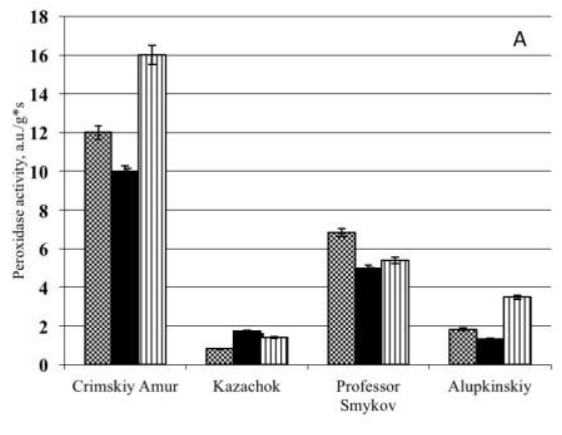

Eull watering

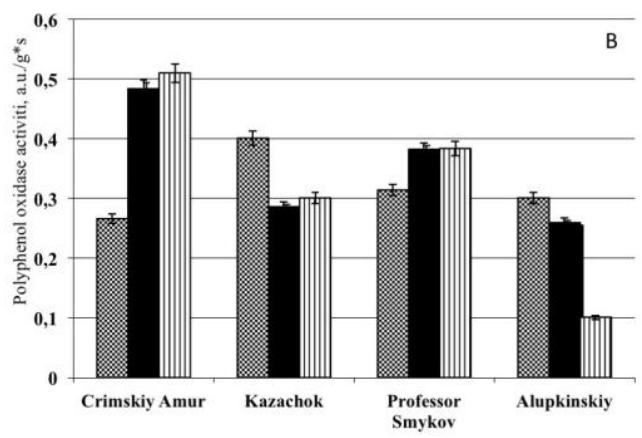

QRestoration of turgor

Fig. 1. Peroxidase (A) and polyphenol oxidase (B) activity in the leaves of $P$. armeniaca varieties depending on the dehydration degree

Studies have shown that drought-resistant apricot varieties in conditions of increasing water stress and subsequent restoration of peroxidase activity changes were characterized by relatively low amplitude.

High water deficiency contributed to the growth of proline content in leaf tissues of all varieties (by 7-12 times), and restoration of water supply was accompanied by a decrease in its concentration. The obtained results allow to conclude about the participation of proline as a protective compound in regulation of stress state in $P$. armeniaca genotypes.

The analysis of primary photosynthesis processes in the studied apricot varieties showed that dehydration close to the sublethal water deficiency level leads to complete inactivation of FS 2 in 'Krymskiy Amur' and 'Alupkinsky' varieties, as evidenced by a decrease in the viability index below the vital norm ( 0.95 and 0.87 c.u., respectively). In the turgidity restoration process of stable varieties, there was an increase in basic fluorescence (on average by $15-20 \%$ ), which was due to an increase in losses during migration of excitation energy along pigment matrix. 'Alupkinsky' variety with high sensitivity to dehydration showed an extraordinary increase $\left(\mathrm{Fpl}-\mathrm{F}_{0}\right) / \mathrm{Fv}(214 \%)$, indicating deep violations of recovery processes $Q_{a}$ at FS2 reaction centers. It was found that prolonged dehydration caused the destruction of FS2 in varieties with low drought resistance - 'Krymskiy Amur' and 'Alupkinsky'. This is confirmed by extremely low values (Fm-Fst) /Fst - 1.54 and 0.98 cu., as well as Fv/F 0 (1.54 and 1.87) ratios associated with the state of the oxygen-releasing complex. In drought-resistant varieties, the restoration of leaf tissue water availability was accompanied by the return of the main CFI parameters to values close to the control values. Only the ratio of variable and basic fluorescence $(<4)$ showed the persistence of the stress state.

In the laboratory experiment conditions, it was established that under controlled wilting at the beginning of the summer season (May), the proline concentration decreased in all studied figs varieties, and with the restoration of water supply it was increased (on average by $28-30 \%$ ). The least sharp fluctuations in the content of this amino acid occurred in the resistant 'Sabrucia Rozovaya' varietychanges did not exceed $9 \%$. During periods of maximum probability of draught weather occurrence (2nd decade of June-July), a multidirectional change in the proline concentration was observed in the wilting process and an increase (by 14.6-132.6\%) in the water supply restoration. Stable varieties 'Sabrucia Rozovaya' and 'Sary Stambulskiy' were characterized by relative stability of proline concentration. As a result of this amino acid content changes analysis at the end of July, differences related to the degree of drought resistance of the studied figs varieties were revealed (Figure 1). In the leaves of all studied varieties, the content of proline increased after wilting (by 19.8-48.2\%) and 
decreased (by 12.2-16.3\%) after turgidity restoration in resistant varieties and increased in not droughtresistant varieties.
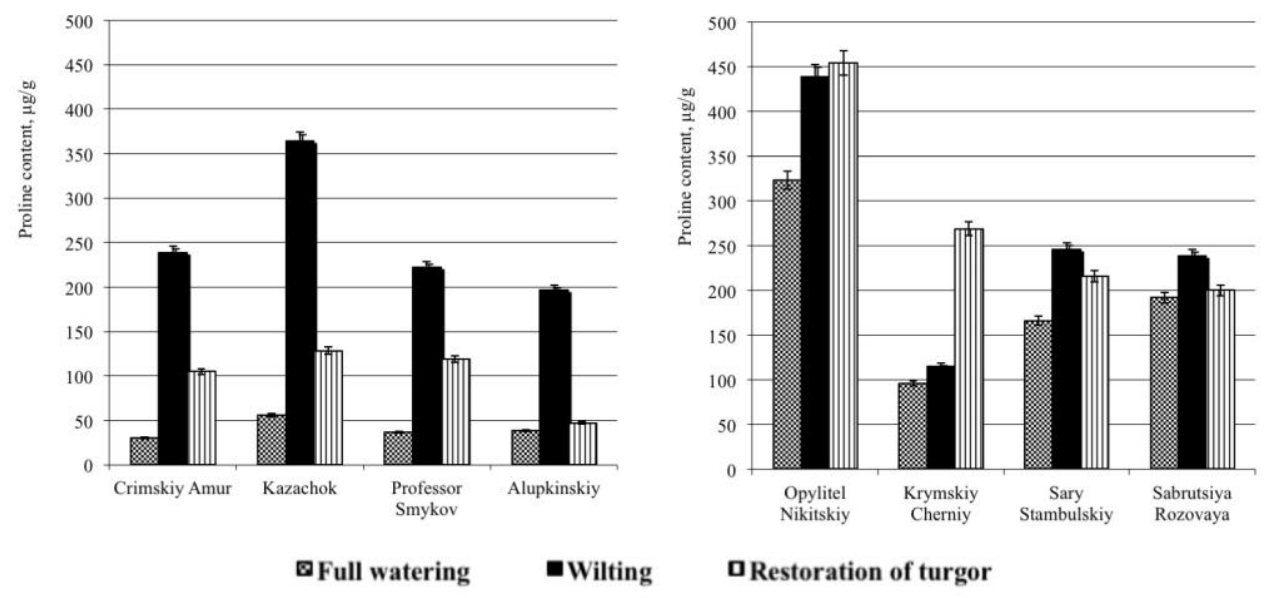

Fig. 2. Change in proline concentration in the leaves of $F$. carica and $P$. armeniaca varieties depending on the dehydration degree

As a result of studying the work of polyphenol oxidase and peroxidase in controlled fig leaf wilting, it was found that during the early summer season (late May), both peroxidase and polyphenol oxidase activity increased with dehydration and decreased after stress impact relief. However, during periods of high hydrothermal stress development probability (June-July), multidirectional changes in enzymatic activity were observed. In June, in conditions of water status restoration, there was a further increase in enzyme activity in all studied varieties (by 15.0-287.9\%), which indicates the development of destructive processes. In July, in similar conditions of the experiment, differences related to the degree of drought resistance of the studied figs were revealed: in drought-resistant varieties, dehydration of leaves was accompanied by activation of enzymes, and the process of turgidity restoration - by activity decrease (Figure 2). After wilting, peroxidase activity increased by 1.4-2.7 times in the leaves of resistant plants, and after restoration of water status - decreased by 1.5-5.4 times. Polyphenol oxidase activity in drought-resistant varieties increased by 2.2-3.4 times after dehydration and slightly decreased after the turgidity restoration in 'Sabrucia Rozovaya' variety (by $7.6 \%$ ) and did not change in the 'Sary Stambulskiy' variety. In non-drought-resistant varieties, the enzymes activity at wilting changed multidirectionally, and then increased after the restoration of water supply. The obtained data indicate that the critical stage in the implementation of protective mechanisms against the negative influence of water stress for $F$. carica varieties leaves is the end of June-beginning of July, which, in turn, may be due not only to adverse weather conditions, but also to fruit load. 


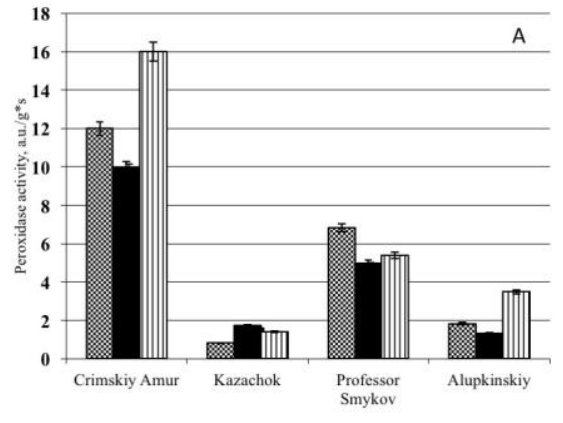

Eull watering

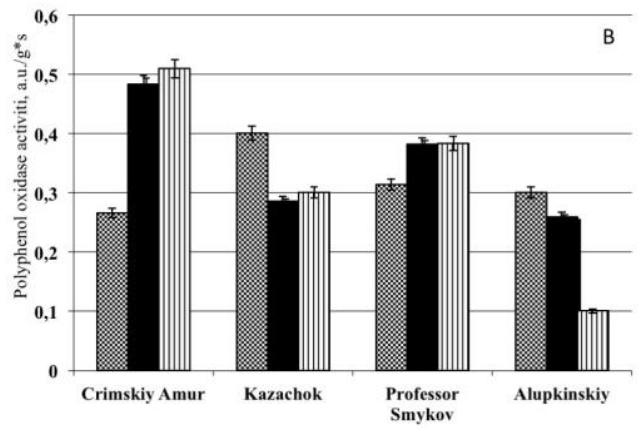

Destoration of turgor

Fig. 3. Peroxidase activity in the leaves of $F$. carica varieties in conditions of water stress

As a result of experiments on controlled wilting, it was found that water stress in $F$. sarica varieties has a significant effect on the parameters of the rapid fluorescence phase. Varieties 'Sabrucia Rozovaya', 'Opylitel Nikitsky', 'Krymskiy Cherniy' showed a decrease in basic fluorescence by $12-20 \%$, which indicates a decrease in chlorophyll amount in the FS 2 reaction centers. The level of maximum and variable fluorescence decreased in almost all F. carica varieties, but was mostly pronounced in non-dehydration-resistant variety 'Opylitel Nikitsky' (25\% and 30\%, respectively).

When restoring water supply, violations in the work of the photosynthetic apparatus were manifested most clearly. The increase in the basic fluorescence level in all studied genotypes (in drought-sensitive variety 'Opylitel Nikitsky' $\mathrm{F}_{0}$ increased by $127 \%$ ). This pattern indicates the beginning of irreversible violations in the work of FS 2, probably associated with the destruction of the quantasomes structure. It should be noted that in these conditions of the experiment, the vitality index at the boundary of the vital norm was noted in varieties 'Sabrucia Rozovaya' and 'Sary Stambulskiy'.

\section{Conclusion}

Analysis of drought resistance of P. armeniaca and F. carica showed that apricot varieties Kazachok and Professor Smykov and figs varieties 'Sabrucia Rozovaya' and 'Sary Stambulskiy' are resistant to inadequate water supply. Relationship of drought resistance degree of P. armeniaca varieties with a change in proline content in the leaves was revealed. It has been shown that stable peroxidase activity preservation is characteristic for stable apricot genotypes under conditions of water stress. Study of primary photosynthesis processes in apricot showed that deep dehydration causes an increase in basic fluorescence. 'Krymskiy Amur' and 'Alupkinsky' varieties were characterized by low resistance of FS2 to lack of moisture. Leaves' loss of $15-20 \%$ of water leads to irreversible violations in the work of the photosynthetic apparatus.

It was found that the leaves' loss of $10-15 \%$ of moisture in F. carica varieties corresponds to sublethal water deficit. Leaves of non-drought-resistant varieties differ from resistant genotypes by the dynamics of proline content, as well as peroxidase and polyphenol oxidase activity. The analysis of the obtained data suggests that the antioxidant system of 'Sabrucia Rozovaya' and 'Sary Stambulskiy' varieties can quickly react to changes in leaf water supply. In F. carica varieties, the characteristics of the rapid phase of chlorophyll fluorescence are the CFI parameters most sensitive to lack of water availability. In the studied figs varieties, it was revealed that violations during primary photosynthesis 
processes caused by dehydration are most clearly manifested after turgidity restoration of leaf tissues.

\section{Acknowledgement.}

The research was performed on the equipment of the Multiple-access Center "Physiological and biochemical studies of plant objects" (FBI RO) FSBSI "NBS-NNC" (Yalta, Russia)

\section{References}

1. M.M. Chaves, M.M. Oliveira, J. Exp. Bot., 55, 2365 (2004)

2. X. Li, F. Liu, M. Wani, S. Bhattacharjee, S. Burritt, D. Tran, Drought Stress Tolerance in Plants, 1, 17 (2016)

3. X. Liang, L. Zhang, S.K. Natarajan, D.F. Becker, Antioxid. Redox Signal, 19, 998 (2013)

4. A. Oukarroum, S.E. Madidi, G. Schansker, R.J. Strasser, Environmental and Experimental Botany, 60, 438 (2007)

5. V.N. Goltsev, M.H. Kalaji, M.A. Kouzmanova, S.I. Allakhverdiev. Variable and Delayed Chlorophyll a Fluorescence - Basics and Application in Plant Sciences (2014)

6. N.A. Gaevsky, V.N. Morgun. Plant Physiology, 40-4, 136 (1993)

7. E. Rosenqvist, O.V. Kooten. Chlorophyll fluorescence: a general description and nomenclature. Practical applications of chlorophyll fluorescence in plant biology 32 (2003)

8. S.P. Makarenko, V.A. Trufanov, T.E. Putilina, The effect of high temperatures on the photosynthetic activity of intact barley leaves at low and high irradiance, 49-3, 326 (2002)

9. T.B. Gubanova, R.A. Pilkevich, A.A. Kharchenko, I.V. Bernatsky, Plant Biology and Horticulture: theory, innovation, 2(151) 109 (2019)

10. V. Gorina., N. Mesiats, V. Korzin, Y. Ivashchenko. Studies of chlorophyll fluorescence intensity in apricot leaves during wilting processes. Acta Horticulturae, 1242, 633 (2019)

11. V.K. Andriushchenko, V.V. Saianova, A.A. Zhuchenko, N.I. D'iachenko, L.A. Chilikina, V.V. Drozdov, S.K Korochkina, G.I. Cherep, V.V. Medvedev, Iu.I. Niutin, Bulletin of the Academy of Sciences of the Moldavian SSR, 4, 55 (1981)

12. A.I. Ermakov, Methods of plants biochemical research. Leningrad: Agropromizdat, 430 (1987)

13. V.A. Romanov, I.B. Galelyuka, Ie.V. Sarakhan, Sensor Electronics and Microsystem Technol, 1-7-3, 39 (2010)

14. A.I. Lishchuk, Physiological and biophysical methods in fruit crops breeding. Guidelines (1991) 